\title{
Sigma-2 Receptors as Potential Novel Biomarkers During the Progression of Benign Prostatic Hypertrophy (BPH) into Prostate Cancer
}

\author{
Nicola Antonio Colabufo, ${ }^{*, a}$, Pasquale Saponaro ${ }^{\mathrm{b}, \mathrm{c}}$, Michele Bottalico ${ }^{\mathrm{b}, \mathrm{c}}$, Marialessandra Contino ${ }^{\mathrm{a}}$, \\ Carmela Inglese ${ }^{\mathrm{a}}$, Vincenzo Pagliarulo ${ }^{\mathrm{c}}$, Arcangelo Pagliarulo ${ }^{\mathrm{c}}$, Francesco Berardi ${ }^{\mathrm{a}}$ and Roberto Perrone ${ }^{\mathrm{a}}$
}

\author{
${ }^{a}$ Dipartimento Farmacochimico, Facoltá di Farmacia, Universitá degli Studi di Bari, via Orabona, 4, 70125, Bari, Italy \\ ${ }^{b}$ Unità Operativa di Urologia, Casa di Cura Santa Maria, SPA, Via De Ferrariis 18/D, 70124 Bari, Italy \\ ${ }^{c}$ Dipartimento Emergenza e Trapianti d'Organo, Sezione di Urologia, Universitá degli Studi di Bari, Piazza G. Cesare, \\ 11, 70124, Bari, Itay
}

\begin{abstract}
BPH could be considered the most common benign tumor for men between 60 and 75 years of age. PSA is an unsatisfactory biomarker to define BPH progression to cancer. Recently, sigma-2 receptors have been recognized in several prostate cancer cell lines such as PC-3, DU-145 and LNCaP. It is reported that, in some cases, BPH could progress to malignancy and this progression can not easily be monitored by biomarkers such as PSA. In this paper we investigated 10 specimens from TURP, finding overexpression of sigma-2 receptors in two of these specimens (specimen 1 and 2 ) accompanied by $4 \mathrm{ng} / \mathrm{mL}$ PSA values. We hypothesize that the presence of sigma- 2 receptors is related to a BPH progressing in prostate cancer. A possible correlation between sigma-2 receptors and PSA values could be useful to identify this pathological progression.
\end{abstract}

Keywords: Sigma-2 receptors, benign prostate hypertrophy, PSA.

\section{INTRODUCTION}

Benign Prostatic Hypertrophy (BPH) is characterized by hyperplasia of prostatic stromal and epithelial cells, resulting in the formation of large, fairly discrete nodules in the periurethral region of the prostate $[1,2]$. These nodules, if sufficiently large, compress the urethral canal causing partial or complete obstruction of the urethra, modulating the normal urine flow. These epithelial cells actively proliferate but do not frequently progress to malignancy, so that $\mathrm{BPH}$ could be considered the most common benign tumor in men between 60 and 75 years of age.

Prostate Specific Antigen (PSA), synthesized only by prostatic gland cells, is a sensitive and specific marker for prostatic diseases, including Benign Prostatic Hypertrophy $(\mathrm{BPH})$, prostatitis and cancer. Clinically, total PSA values $>4 \mathrm{ng} / \mathrm{mL}$ are considered pathological, whilst values $>10$ $\mathrm{ng} / \mathrm{mL}$, are strongly suggestive of malignancy. PSA levels may be elevated in these patients because of increased organ volume and inflammation due to urinary tract infections [36], thus BPH can not be always considered a premalignant lesion [7]. FDA approved PSA test in conjunction with a digital rectal examination to detect prostate cancer. However, much remains unknown about the interpretation of PSA levels and hence they can not be considered a definitive test. For this reason, after transurethral resection of the prostate (TURP), (the most common surgery for BPH, [8]), the removed tissue is subjected to histological and immunohistochemical analysis. However, these investigations discrimi-

*Address correspondence to this author at the Dipartimento Farmacochimico, Facoltá di Farmacia, Universitá degli Studi di Bari, via Orabona, 4, 70125, Bari, Italy; E-mail: colabufo@farmchim.uniba.it nate only between $\mathrm{BPH}$ and prostate cancer, whilst the progression of BPH to malignancy can not be detected [9].

Sigma receptors are endocellular sites involved in tumor progression; in fact it has been demonstrated that these receptors are overexpressed in several tumor cell lines and tissues [10]. Recently, our research group demonstrated that sigma-2 and sigma-1 receptors are overexpressed in tumor cell lines such as rat C6 glioma, MCF-7 human breast adenocarcinoma, SK-N-SH human neuroblastoma, murine mammarian sarcoma EMT-6 and in TRAnsgenic Mouse Prostate (TRAMP) cells [11].

In particular, we have recognized these receptors in human bladder carcinoma, thereby establishing a correlation between sigma-2 receptor expression level and tumor staging and grading [12]. By contrast, a correlation between sigma-1 subtype and tumor staging and grading has not been demonstrated. Moreover, it has been reported that human PC-3 androgen-insensitive [13] and LnCap androgen-sensitive prostate tumour cell lines overexpress sigma- 2 receptors [14].

The aim of the present work is to verify if sigma-2 receptors, could be additional biomarkers to characterize $\mathrm{BPH}$, in particular for specimens displaying ambiguous PSA level. Our objective is to identify the progression of BPH to malignancy where other diagnostic tools have failed.

Following our protocol for the characterization of sigma receptor recognition in human bladder tumor, the stage and grade of the tumor was correlated with the expression of these receptors [12]. Ten specimens from TURP were examined in order to establish a possible correlation between $\mathrm{BPH}$ and sigma receptor density. 


\section{MATERIALS AND METHODS}

\section{Radioligand and Drugs}

The radioligand $\left[{ }^{3} \mathrm{H}\right]-\mathrm{DTG}(56 \mathrm{Ci} / \mathrm{mmol}),(+)-\left[{ }^{3} \mathrm{H}\right]-$ pentazocine $(32 \mathrm{Ci} / \mathrm{mmol})$ were purchased from PerkinElmer Life Sciences (Zavantem, Belgium). (+)-Pentazocine was obtained from Sigma-Aldrich s.r.l. (Milan, Italy). DTG was purchased from Tocris Cookson Ltd., UK.

\section{Membrane Preparation}

The membrane preparations were carried out as described by Colabufo et al. with minor modifications [12]. Briefly, $500 \mathrm{mg}$ human prostate tissue was homogenized with a Brinkman polytron (setting 5 for $3 \times 15 \mathrm{~s}$ ) in ice-cold-buffer $(20 \mathrm{~mL})$ containing $0.32 \mathrm{M}$ sucrose and $10 \mathrm{mM}$ Tris $\mathrm{pH}$ 7.4. The homogenate was centrifuged at $4{ }^{\circ} \mathrm{C}$ at $1,000 \times \mathrm{g}$ for 10 minutes and the supernatant saved. The pellet was resuspended in $20 \mathrm{~mL}$ Tris-sucrose buffer and centrifuged again at $4{ }^{\circ} \mathrm{C}$ at $1,000 \times \mathrm{g}$ for 10 minutes. The supernatants from both $1,000 \times \mathrm{g}$ spins were combined and ultra-centrifuged at $4{ }^{\circ} \mathrm{C}$ at $31,000 \times \mathrm{g}$ for 15 minutes. The pellet was resuspended in $20 \mathrm{~mL}$ of $10 \mathrm{mM}$ Tris (pH 7.4). The homogenate was incubated at $25{ }^{\circ} \mathrm{C}$ for 30 minutes then centrifuged at $31,000 \times \mathrm{g}$ for 15 minutes. The final pellet was resuspended in $10 \mathrm{mM}$ Tris- $\mathrm{HCl}(\mathrm{pH} 7.4)$ and stored at $-80{ }^{\circ} \mathrm{C}$ until use. For each membrane preparation the protein content was determined by the Lowry method.

\section{Saturation Binding Assay}

The saturation experiments were carried out as described by Colabufo et al. with minor modifications [12]. Sigma-2 receptors in prostate specimens membranes were radiolabeled using [ $\left.{ }^{3} \mathrm{H}\right]-\mathrm{DTG}$ ligand, with concentrations ranging $1.0-150 \mathrm{nM}$. Samples containing $250 \mu \mathrm{g}$ of membrane protein, radioligand, $10 \mu \mathrm{M}$ DTG (to determine non-specific binding) and $1 \mu \mathrm{M}(+)$-pentazocine (to mask sigma- 1 receptors), were equilibrated in a final volume of $250 \mu \mathrm{L}$ of 50 $\mathrm{mM}$ Tris $\mathrm{pH} 8.0$ for 120 minutes at $25^{\circ} \mathrm{C}$. Incubations were stopped by addition of $5 \mathrm{~mL}$ of ice-cold buffer, and then the suspension was filtered through GF/B pre-soaked in $0.3 \%$

A

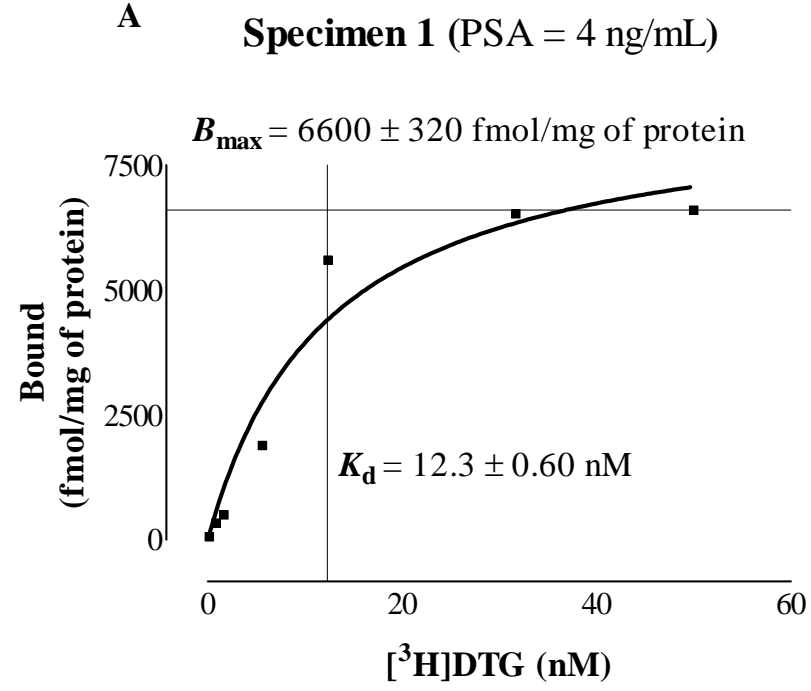

poly(ethylenimine) for at least 60 minutes prior to use. The filters were washed twice with $5 \mathrm{~mL}$ of ice-cold buffer.

The saturation experiments for labeling sigma- 1 receptors were carried out employing the same procedure excepting for $(+)-\left[{ }^{3} \mathrm{H}\right]-$-pentazocine to radiolabel sigma- 1 receptors (concentrations ranging 1.0-15 nM). The non-specific binding has been determined with $10 \mu \mathrm{M}(+)$-pentazocine.

\section{RESULTS}

The experimental data was derived from ten men (age 60-75 years) receiving pharmacological treatment (alpha adrenergic antagonist such as alphuzosin and tamsulosin).

The presence of sigma- 1 and sigma- 2 receptors in each specimen was recognized by saturation analysis with (+)$\left[{ }^{3} \mathrm{H}\right]$-pentazocine and $\left[{ }^{3} \mathrm{H}\right]-\mathrm{DTG}$, specific radioligands targeting these receptors. In this assay, several concentrations of radioligand were added to constitute the receptor-radioligand complex. Two parameters were calculated by saturation analysis: $K_{\mathrm{d}}$ and $B_{\max }$. The $K_{\mathrm{d}}$ value indicates the radioligand concentration, at equilibrium, that binds $50 \%$ of total sigma2 receptors present in the biological sample. This value could vary from $10 \mathrm{nM}$ to $30 \mathrm{nM}$ for $\left[{ }^{3} \mathrm{H}\right]$-DTG and from $1 \mathrm{nM}$ to $5 \mathrm{nM}$ for $(+)-\left[{ }^{3} \mathrm{H}\right]$-pentazocine, depending on the tissues and the cells employed. Moreover, through this analysis, sigma-2 receptors population is quantified by the $B_{\max }$ value. This value indicates the receptor density and it is expressed as $\mathrm{fmol} / \mathrm{mg}$ of protein.

All specimens have been studied by saturation analysis with radioligand, but only two of these specimens, namely $\mathbf{1}$ and 2, overexpressed sigma-2 receptors. Unfortunately, in the same specimens sigma- 1 receptors have not been detected because of high non specific binding. In the other samples, $K_{\mathrm{d}}$ and $B_{\max }$ values were not determined because of the low expression of sigma- 2 receptors.

In Fig. (1A) the saturation binding assay of specimen $\mathbf{1}$ is reported. In this sample sigma- 2 receptors are overexpressed $\left(B_{\max }=6600 \pm 320 \mathrm{fmol} / \mathrm{mg}\right)$ and $K_{\mathrm{d}}$ value was $12.3 \pm 0.60$ nM. Analogously, in specimen $2 K_{\mathrm{d}}=22.59 \pm 1.10 \mathrm{nM}$ and $B_{\max }=6500 \pm 325 \mathrm{fmol} / \mathrm{mg}$ of protein have been found (Fig.

B

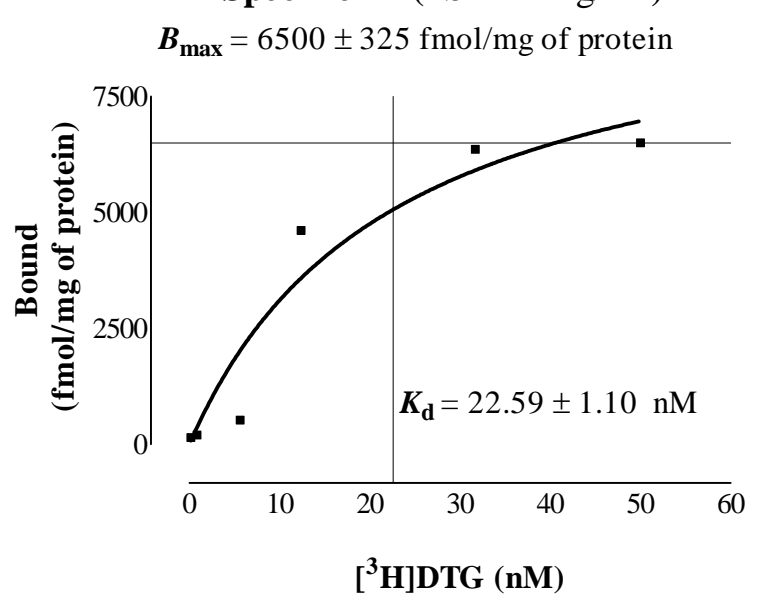

Fig. (1). Representative radioligand saturation analysis curve for recognition of sigma-2 receptors in Specimen 1 (A) and in Specimen 2 (B). 
1B). These results demonstrated that $K_{\mathrm{d}}$ values of each specimen were consistent with the $K_{\mathrm{d}}$ range reported above. Moreover, in both biological samples, similar sigma-2 receptor overexpression was found. Before TURP, 8 patients displayed total PSA levels $\leq 2 \mathrm{ng} / \mathrm{ml}$ and specimens 1 and 2 displayed a PSA level of $4 \mathrm{ng} / \mathrm{ml}$.

\section{DISCUSSION}

The prostate pathology can be divided in three progressive steps: (1) BPH in a non progressive state; (2) BPH progressing into prostate cancer; (3) prostate cancer. PSA is a robust diagnostic tool for prostatic cancer, nevertheless it can not be considered a definitive test.

It has been demonstrated that sigma- 2 receptors are overexpressed in several prostate tumor cell lines such as PC-3 and DU-145 (androgen-independent cells) and in LNCaP (androgen-dependent cells) [14]. Therefore, sigma-2 receptors as well as PSA displayed high sensitivity in prostate cancer (step 3) but only sigma-2 receptors are sensitive to step 2 as found in the present paper. The combination of these two biomarkers can identify steps 2 and 3 however sigma-2 receptors are unable to characterize (or diagnose) $\mathrm{BPH}$ in non progressive state.

\section{CONCLUSION}

The present study is a contribution to better characterize $\mathrm{BPH}$ progression into prostate cancer where PSA alone is considered an unsatisfactory biomarker. Although these studies are focused on few samples it is possible to hypothesise that the detection of PSA $>4 \mathrm{ng} / \mathrm{mL}$ accomplished with high sigma-2 receptor density could led to a BPH progression into prostate cancer. By contrast the role of sigma 1 receptors should be elucidated yet.

$$
\begin{aligned}
& \text { ABBREVIATIONS } \\
& \mathrm{BPH}=\text { Benign Prostatic Hypertrophy } \\
& \text { PSA } \quad=\text { Prostate Specific Antigen } \\
& \text { PC-3 = Human androgen-insensitive prostate tumor } \\
& \text { cell line } \\
& \text { DU-145 = Human androgen-insensitive prostate tumor } \\
& \text { LnCap = Human androgen-sensitive prostate tumor } \\
& \text { cell line } \\
& \text { TURP }=\text { Transurethral resection of the prostate } \\
& \text { SK-N-SH = Human neuroblastoma cell line }
\end{aligned}
$$

\section{EMT-6 = Murine mammarian Sarcoma}

MCF-7 = Human breast adenocarcinoma

$K_{\mathrm{d}}=$ Dissociation constant of radioligand-receptor complex at the equilibrium.

$B_{\max } \quad=$ Receptor density expressed as $\mathrm{fmol} / \mathrm{mg}$ of the protein

\section{REFERENCES}

[1] Nickel JC. Inflammation and benign prostatic hyperplasia. Urol Clin North Am 2008; 35: 109-15.

[2] Rhodes PR, Krogh RH, Bruskewitz RC. Impact of drug therapy on benign prostatic hyperplasia-specific quality of life. Urology 1999; 53: 1090-8.

[3] Mosquera MJ, Pinto SI, Enguix AA, Sahagún AJL. Usefulness of free/total PSA ratio and PSA density in distinguishing benign prostatic hypertrophy from prostatic cancer. Actas Urol Esp 2001; 9: 651-5.

[4] Minardi D, Galosi AB, Recchioni A, Giammarco L, Polito M, Muzzonigro G. Diagnostic accuracy of percent free prostatespecific antigen in prostatic pathology and its usefulness in monitoring prostatic cancer patients. Urol Int 2001; 67: 272-82.

[5] Villers A, Chautard D. Free PSA: its routine use is premature in the screening of prostatic cancer. Prog Urol 2000; 10: 618-21.

[6] Belanger A, van-Halbeek H, Graves HC, et al. Molecular mass and carbohydrate structure of prostate specific antigen: studies for establishment of an international PSA standard. Prostate 1995; 27: 187-97.

[7] Berry SJ, Coffey DS, Walsh PC, Ewing LL. The development of human benign prostatic hyperplasia with age. J Urol 1984; 132: 474-9.

[8] Tubaro A. BPH treatment: a paradigm shift. Eur Urol 2006; 49: 939-41.

[9] Kang D, Chokkalingam AP, Gridley G, et al. Benign prostatic hyperplasia and subsequent risk of bladder cancer. $\mathrm{Br} \mathrm{J}$ Cancer 2007; 96: 1475-9.

[10] Vilner BJ, John CS, Bowen WD. Sigma-1 and sigma-2 receptors are expressed in a wide variety of human and rodent tumor cell lines. Cancer Res 1995; 55: 408-13.

[11] Colabufo NA, Abate C, Contino M, et al. PB183, a sigma receptor ligand, as a potential PET probe for the imaging of prostate adenocarcinoma. Bioorg Med Chem Lett 2008; 18: 1990-3.

[12] Colabufo NA, Berardi F, Contino M, et al. Correlation between sigma $_{2}$ receptor protein expression and histopathologic grade in human bladder cancer. Cancer Lett 2006; 237: 83-8.

[13] Mégalizzi V, Mathieu V, Mijatovic T, et al. 4-IBP, a $\sigma_{1}$ Receptor agonist, decreases the migration of human cancer cells, including glioblastoma cells, in vitro and sensitizes them in vitro and in vivo to cytotoxic insults of proapoptotic and proautophagic drugs. Neoplasia 2007; 9: 358-69.

[14] John CS, Vilner BJ, Geyer BC, Moody T, Bowen WD. Targeting sigma receptor-binding benzamides as in vivo diagnostic and therapeutic agents for human prostate tumors. Cancer Res 1999; 59: 4578-83.

(C) Colabufo et al:; Licensee Bentham Open.

This is an open access article licensed under the terms of the Creative Commons Attribution Non-Commercial License (http://creativecommons.org/licenses/by-nc/3.0/) which permits unrestricted, non-commercial use, distribution and reproduction in any medium, provided the work is properly cited. 